\title{
PENGARUH PARTISIPASI ANGGARAN, KEJELASAN SASARAN ANGGARAN, DESENTRALISASI, DAN AKUNTABILITAS PUBLIK TERHADAP KINERJA MANAJERIAL
}

\section{THE INFLUENCE OF BUDGET PARTICIPATION, BUDGET CLARITY, DECENTRALIZATION, AND PUBLIC ACCOUNTABILITY ON MANAGERIAL PERFORMANCE}

\author{
Febdwi Suryani ${ }^{1}$, Pujiono $^{2}$ \\ Institut Bisnis dan Teknologi Pelita Indonesia ${ }^{1,2}$ \\ febdwi.suryani@1ecturerpelitaindonesia.co.id ${ }^{1}$
}

\begin{abstract}
This study aimed to analyze the effect of budget participation, clarity of budget targets, decentralization, and public accountability on managerial performance. Population of this research was 31 Regional Apparatus Organizations (OPD) in Pekanbaru City, there are officials at the head level, heads of offices / sections / fields / sub-services, secretaries, and heads of subsections / sub-sectors / sections of the secretariat, agencies, and officed. The data was collected by distributing questionnaires to 124 respondents, while the questionnaires that could be used were only 89 respondents. Data were analyzed using multiple linear analysis. The results of the analysis found that there is a significant influence between budget participation and managerial performance, there is no significant influence between the clarity of budget targets on managerial performance, there is a significant influence between decentralization and managerial performance, and there is no significant influence between public accountability on managerial performance. The result of testing the coefficient of determination of the hypothesis in this study was 50.3\%, while the remaining $49.7 \%$ was influenced by other variables not included in this study. The value of t table in this study is 1.662, while the $t$ value of the first hypothesis is $-17,166>-1,668$, the second hypothesis is 20,107> 1,668, the third hypothesis is $-2,481>-1,668$, and the fourth hypothesis is $-2,248>-1,668$.
\end{abstract}

Keywords: Managerial Performance, Budget Participation, Clarity of Budget Objectives, Decentralization, and Public Accountability.

\begin{abstract}
ABSTRAK
Penelitian ini bertujuan untuk menganalisis tentang pengaruh partisipasi anggaran, kejelasan sasaran anggaran, desentralisasi, dan akuntabilitas publik terhadap kinerja manajerial. Populasi penelitian ini berjumlah 31 Organisasi Perangkat Daerah (OPD) yang ada di Kota Pekanbaru yaitu pejabat setingkat kepala, kepala dinas/bagian/bidang/subdinas, sekretais, dan kepala subbagian / sub bidang/seksi dari sekretariat, badan, dinas dan kantor. Pengumpulan data dilakukan dengan membagikan kuesioner kepada 124 responden, sedangkan kuesioner yang dapat digunakan hanya berjumlah 89 responden. Data dianalisis dengan menggunakan analisis linear berganda. Hasil analisis menemukan bahwa terdapat pengaruh signifikan antara partisipasi anggaran dengan kinerja manajerial, tidak terdapat pengaruh dan tidak signifikan antara kejelasan sasaran anggaran terhadap kinerja manajerial, terdapat pengaruh signifikan
\end{abstract}


antara desentralisasi dengan kinerja manajerial, dan tidak terdapat pengaruh dan tidak signifikan antara akuntabilitas publik terhadap kinerja manajerial. Hasil pengujian koefisien determinasi hipotesis pada penelitian ini sebesar 50,3\%, sedangkan sisanya sebesar $49,7 \%$ dipengaruhi oleh variabel lain yang tidak termasuk dalam penelitian ini. Nilai $t$ tabel dalam penelitian ini sebesar 1,662, sedangkan $t$ hitung dari hipotesis pertama sebesar $-17,166>-1,668$, hipotesis kedua sebesar 20,107 $>1,668$, hipotesis ketiga sebesar $-2,481>-1,668$, dan hipotesis keempat sebesar -2,248 $>-1,668$.

Kata Kunci : Kinerja Manajerial, Partisipasi Anggaran, Kejelasan Sasaran Anggaran, Desentralisasi, dan Akuntabilitas Publik.

\section{PENDAHULUAN}

Pelaksanaan otonomi daerah yang ditandai dengan diberlakukannya Undang-Undang No. 22 dan 25 Tahun 1999 yang diperbaharui dengan Undang-Undang Nomor 32 dan 33 Tahun 2004 tentang Pemerintah Daerah menjadi babak baru terkait hubungan antara pemerintah pusat dengan pemerintah daerah. Pelaksanaan otonomi daerah memberikan wewenang yang lebih besar bagi pemerintah daerah untuk mengatur dan mengurus rumah tangganya sendiri. Pemanfaatan sumber daya dilakukan secara ekonomis, efisien, efektif, adil dan merata untuk mencapai akuntabilitas publik. Pemerintah daerah memerlukan instrumen anggaran dalam mengelola sumber daya yang ada dengan baik, untuk mencapai kinerja yang baik yang diharapkan oleh masyarakat (Wahyuni, et.al, 2014).

Anggaran berbasis kinerja merupakan sistem yang mencakup penyusunan dan tolok ukur kinerja sebagai instrumen untuk mencapai tujuan dan sasaran program. Kinerja sektor publik sebagian besar dipengaruhi oleh kinerja aparat atau kinerja manajerial, hal ini dikarenakan semakin baiknya kinerja seorang manajer akan berpengaruh dengan semakin baiknya kinerja organisasi tersebut (Mukaromah, 2018).

$$
\text { Kinerja manajerial OPD }
$$
mempunyai arti yang sangat penting dalam rangka pelaksanaan pemerintah dan kegiatan pembangunan oleh pelayanan masyarakat di daerah, oleh karena itu kinerja OPD diupayakan untuk berjalan secara berdaya guna dan berhasil guna. Penilaian kinerja pada pemerintah sangat penting dilakukan agar dapat meningkatkan kualitas pelayanan publik dan mengevaluasi kinerja periode yang lalu, agar dapat dijadikan sebagai dasar penyusunan strategi pemerintah untuk periode berikutnya. Kinerja juga merupakan salah satu kunci keberhasilan OPD dalam menjalankan tugasnya di pemerintah daerah, karena dengan kinerja yang baik pencapaian good governance akan senantiasa terbuka lebar (Arum, 2016).

Kinerja manajerial merupakan prestasi seseorang dalam bekerja dimana manajer dapat mencapai tujuan organisasi yang disesuaikan dengan visi, misi dan sasaran organisasi (Ermawati, 2017). Beberapa faktor yang dapat mempengaruhi kinerja manajerial OPD, diantaranya adalah partisipasi anggaran, kejelasan sasaran anggaran, desentralisasi, dan akuntabilitas publik (Wahyuni, et.al, 2014).

Menurut Arum (2016), manajer diharapkan ikut berpartisipasi dalam penyusunan anggaran untuk meningkatkan kinerja unit organisasi. Hal ini didasarkan pada pemikiran bahwa ketika suatu tujuan/standar yang dirancang secara partisipati disetujui 
oleh pimpinan, maka pegawai akan bersungguh-sungguh dalam tujuan/standar yang telah ditetapkan dan pegawai juga memiliki rasa tanggung jawab pribadi untuk mencapainya karena ikut serta terlibat dalam penyusunannya agar dapat meningkatkan kinerja pemerintah. Disamping itu, organisasi perlu menyusun target-target anggaran sesuai dengan sasaran yang ingin dicapai organisasi melalui kejelasan sasaran anggaran.

Kenis dalam Arum (2016), kejelasan sasaran anggaran berfungsi untuk mengukur sejauh mana sasaran anggaran telah dirumuskan secara spesifik dan jelas. Kejelasan tujuan anggaran merupakan hal yang paling penting dalam pencapaian suatu tujuan organisasi karena akan menentukan arah tujuan suatu organisasi. Apabila penetapan sasaran anggaran dinyatakan dengan jelas, akan memudahkan pihak yang diberi tanggung jawab atas pencapaiannya untuk mempertanggungjawabkan keberhasilan atau kegagalan akan tugas yang menjadi beban tanggungjawabnya, sebaliknya, jika sasaran anggaran tidak jelas akan menyebabkan pelaksana anggaran menjadi bingung, tidak tenang dan tidak puas dalam bekerja. Hal ini menyebabkan pelaksana anggaran tidak termotivasi untuk mencapai kinerja yang diharapkan.

Selain faktor kejelasan sasaran anggaran, desentralisasi merupakan salah satu faktor yang mempengaruhi kinerja manajerial, yaitu pendelegasian wewenang dan tanggung jawab kepada manajer. Menurut Hidayat (2015), desentralisasi merupakan penyerahan wewenang dari tingkat pemerintahan yang lebih tinggi kepada pemerintahan yang lebih rendah, baik yang menyangkut bidang legislatif, judikatif, atau administratif.
. Desentralisasi memungkinkan organisasi untuk memberikan respons secara cepat dan efektif terhadap masalah karena mereka yang berada paling dekat dengan suatu masalah (manajer lokal) memiliki informasi yang paling baik dan oleh sebab itu dapat memberikan respons lebih baik terhadap kebutuhan-kebutuhan lokal (Lubis, 2011).

Desentralisasi semakin baik jika diukur dengan indikator yang terdiri dari keuangan, program dan kegiatan, keterlibatan kegiatan, serta kepegawaian. Desentralisasi ini akan membuat tanggung jawab yang lebih besar kepada manajerial OPD dalam menjalankan tugas, serta memberikan kebebasan dalam bertindak (Mukaromah, 2018).

Kinerja sektor publik juga menjadikan akuntabilitas publik sebagai faktor yang dapat menilai keberhasilan atau kegagalan kinerja manajerial. Akuntabilitas publik merupakan kewajiban pertanggungjawaban keberhasilan atau kegagalan dalam mencapai tujuan yang ditetapkan sebelumnya, melalui media pertanggungjawaban yang dilaksanakan secara periodik (Wahyuni, et.al, 2014). Melalui akuntabilitas publik dalam peningkatan kinerja manajerial, masyarakat tidak hanya mengetahui anggaran tersebut tetapi juga mengetahui pelaksanaan kegiatan yang dianggarkan (Darmawan, 2016).

$$
\text { Banyaknya faktor yang }
$$
menyebabkan rendahnya kinerja pemerintah masih rendah, juga dapat menyebabkan sistem pengelolaan keuangan masih lemah, dari proses perencanaan, dan Penganggaran Anggaran Pendapatan dan Belanja Daerah (APBD), pelaksanaan APBD, pertanggung jawaban berupa laporan hasil pelaksanaan APBD serta pengawasan. Jika proses penganggaran 
pemerintah daerah selalu terlambat dalam pengesahan APBD, akan menyebabkan program dan kegiatan yang tidak dapat dilaksanakan untuk tahun anggaran berjalan, sehingga terjadi keterlambatan pembangunan daerah (Ernawilis, 2015).

Hasil penelitian yang dilakukan Ernawilis (2015), Susilowati (2016), Darmawan (2016), menggunakan analisis regresi linier berganda menemukan bahwa partisipasi anggaran, kejelasan sasaran anggaran, desentralisasi, dan akuntabilitas publik memiliki pengaruh signifikan terhadap kinerja manajerial aparat. Berbeda dengan hasil penelitian Ermawati (2017), ditemukan bahwa partisipasi anggaran tidak berpengaruh terhadap kinerja manajerial. Diikuti dengan penelitian Mukharomah (2018) yang membuat kesimpulan bahwa desentralisasi tidak memiliki pengaruh terhadap kinerja manajerial. Begitu juga dengan penelitian yang dilakukan oleh Wahyuni, et.al, (2014) dan Amril (2014), menyimpulkan bahwa kejelasan sasaran anggaran dan akuntabilitas publik tidak berpengaruh signifikan terhadap kinerja manajerial aparat pemerintah.

Berdasarkan latar belakang diatas, maka tujuan penelitian ini adalah untuk mengetahui apakah partsipasi anggaran, kejelasan sasaran anggaran, desentralisasi, dan akuntabilitas publik berpengaruh terhadap kinerja manajerial Organisasi perangkat daerah (OPD) Kota Pekanbaru.

Kinerja manajerial merupakan hasil kerja yang dicapai oleh seorang manajer dalam melaksanakan tugasnya secara kualitas dan kuantitas sesuai dengan tanggung jawab yang diberikan kepadanya (Ingkiriwang, 2013). Pengukuran kinerja terhadap manajer organisasi sektor publik sangat penting baik bagi pihak yang memberi amanah (masyarakat) maupun yang diberi amanah.Bagi pemberi amanah, pengukuran kinerja dapat digunakan untuk menilai kinerja para manajer sektor publik, apakah mereka telah menjalankan tugasnya sesuai dengan yang diamanahkan atau tidak (Mahsun dalam Wahyuni, 2014)

Kinerja manajerial yang dimaksud dalam penelitian ini yakni kinerja dari pimpinan SKPD, kepala bidang/kepala bagian/kepala seksi dan kepala sub

bidang/kepala sub bagian/kepala sub seksi dalam kegiatan manajerial yang mencakup perencanaan, investigasi, koordinasi, evaluasi, pengawasan, pemilihan staf, negoisasi dan perwakilan. SKPD (Satuan Kerja Perangkat Daerah) merupakan pusat pertanggungjawaban yang dipimpin oleh seorang kepala satuan kerja dan bertanggung jawab atas entitasnya, misalnya: dinas kesehatan, dinas kependudukan dan catatan sipil, dinas pendidikan, dinas pemuda dan olah raga dan lainnya.

Partisipasi penyusunan anggaran menjelaskan tentang sejauh mana tingkat keterlibatan manajer dalam penyusunan anggaran (Susilowati, 2016). Partisipasi tersebut menunjukkan adanya interaksi antara para karyawan dengan atasannya, dan para karyawan melakukan aktivitas yang diperlukan mulai dari awal penyusunan anggaran, negoisasi, penetapan anggaran akhir dan revisi anggaran yang diperlukan. Tiga aspek yang harus tercakup dalam anggaran sektor publik meliputi aspek perencanaan, aspek pengendalian, dan aspek akuntabilitas publik. Secara rinci anggaran sektor publik berisi tentang besarnya belanja yang harus dikeluarkan untuk membiayai program dan aktivitas yang direncanakan serta cara untuk mendapatkan dana untuk 
membiayai program tersebut (Mahsun dalam Wahyuni, et.al, (2014)).

Adapun dampak positif dalam organisasi sektor publik yaitu (Mukaromah, 2018):

1. Meningkatkan kebersamaan manajemen dalam hal pencapaian tujuan anggaran karena anggaran yang ada merupakan anggaran yang ditetapkan bersama.

2. Meningkatkan kinerja karena merasa bertanggungjawab dalam pencapaian rencana anggaran yang telah disusun bersama.

3. Menambah informasi bagi atasan mengenai lingkungan yang dihadapi yang diperoleh dari bawahan.

4. Mengurangi tekanan terhadap bawahan, karena tujuan yang ditetapkan merupakan tujuan yang relevan dengan kemampuannya.

5. Meningkatkan komunikasi yang positif antara bawahan dengan atasan.

Kenis dalam Arum (2016), kejelasan sasaran anggaran berfungsi untuk mengukur sejauh mana sasaran anggaran telah dirumuskan secara spesifik dan jelas. Kejelasan tujuan anggaran merupakan hal yang paling penting dalam pencapaian suatu tujuan organisasi karena akan menentukan arah tujuan suatu organisasi. Diluar dari alat perencanaan dan pengendalian biaya dan pendapatan dalam suatu organisasi, OPD juga menjadikan anggaran sebagai bentuk evaluasi dan motivasi kinerja bawahan, koordinasi, dan komunikasi.

Penetapan sasaran anggaran yang dinyatakan dengan jelas, akan memberikan kemudahan bagi pelaksana anggaran dalam mempertanggungjawabkan keberhasilan atau kegagalan dalam mencapai tujuan yang telah ditetapkan organisasi, begitu juga sebaliknya, sasaran anggaran yang tidak jelas, maka pelaksana anggaran akan merasakan ketidaknyamanan dan ketidakpuasan dalam bekerja. Hal ini akan mengakibatkan hilangnya motivasi pelaksanaan anggaran dalam mencapai kinerja yang diharapkan.

Menurut undang-undang nomor 32 tahun 2004 tentang Pemerintahan Daerah, desentralisasi dimaknai sebagai penyerahan wewenang pemerintah oleh pemerintah kepada daerah otonom untuk mengatur dan mengurus urusan pemerintahan dalam sistem Negara Kesatuan Republik Indonesia.

Desentralisasi merupakan penyerahan wewenang dari tingkat pemerintahan yang lebih tinggi kepada pemerintahan yang lebih rendah, baik yang menyangkut bidang legislatif, judikatif, atau administrative (Hidayat, 2015)

Desentralisasi ini akan menunjukkan tingkat otonomi yang didelegasikan pada manajerial OPD sehingga manajerial OPD mempunyai tanggung jawab yang lebih besar terhadap perencanaan dan pengendalian serta membutuhkan informasi yang lebih banyak. Organisasi yang strukturnya terdesentralisasi seperti pelaksanaan otonomi daerah di Indonesia maka manajerial OPD mempunyai otonomi yang lebih besar dalam pengambilan keputusan (Wahyuni, et.al, 2014)).

Menurut Mardiasmo (2013), Akuntabilitas publik adalah kewajiban pemegang amanah (agent) untk memberikan pertanggungjawaban, menyajikan, melaporkan, dan mengungkapkan segala aktivitas dan kegiatan yang menjadi tanggungjawabnya kepada pihak pemberi amanah (principal) yang memiliki hak dan kewenangan untuk meminta pertanggungjawabantersebut. Dalam melakukan akuntabilitas publik, organisasi sektor publik berkewajiban memberikan informasi sebagai bentuk pemenuhan hak-hak publik. Hak-hak 
publik itu diantaranya : 1) Hak untuk tahu (right to know), 2) hak untuk diberi informasi ( right to be informed), 3) hak untuk didengar aspirasinya (right to be heard and to be listend to). Organisasi sektor publik dituntut untuk tidak sekedar melakukan akuntabilitas vertical ( vertical accountability), yaitu pelaporan kepada atasan, akan tetapijuga melakukan akuntabilitas horizontal (horizontal Accountability), yaitu pelaporan kepada masyarakat luas."

Hasil penelitian Sari (2015); Hidrayadi (2015) menyatakan bahwa partisipasi anggaran dan desentralisasi berpengaruh terhadap kinerja manajerial. Begitu juga menurut Ernawilis (2015); Putra (2013), menyatakan bahwa kejelasan sasaran anggaran dan akuntabilitas publik berpengaruh terhadap kinerja manjerial. Sedangkan menurut Ermawati (2017); Mukharomah (2018), menyimpulkan bahwa partisipasi anggaran dan desentralisasi tidak berpengaruh terhadap komitmen organisasi. Amril, (2014); Wahyuni, et.al, (2014), menyatakan bahwa kejelasan sasaran anggaran dan akuntabilitas publik tidak berpengaruh terhadap kinerja manjerial.

Pelaksanaan kegiatan organisasi publik tentunya berasal dari dana publik. Kegiatan yang dilakukan organisasi disesuaikan dengan sasaran dan tujuan yang telah ditetapkan, oleh sebab itu, penting bagi organisasi untuk menjaga hubungan kerjasama yang baik antara bawahan dan atasan, pegawai dan manajer.

Menurut Arum (2016), dengan menyusun anggaran secara partisipatif, diharapkan kinerja unit kerja organisasi akan meningkat. Hal ini didasarkan pada pemikiran bahwa ketika suatu tujuan/standar yang dirancang secara partisipatif disetujui oleh pimpinan, maka pegawai akan bersungguh- sungguh dalam tujuan/standar yang telah ditetapkan dan pegawai juga memiliki rasa tanggung jawab pribadi untuk mencapainya karena ikut serta terlibat dalam penyusunannya sehingga dapat meningkatkan kinerja pemerintah.

Kejelasan anggaran sangat penting untuk menilai sejauh mana pencapaian tujuan anggaran dapat dilaksanakan. Sasaran anggaran pemerintah dikatakan tercapai apabila anggaran tersebut sudah ditetapkan dengan jelas dan spesifik, dan mudah dipahami oleh orang yang bertanggungjawab atas anggaran tersebut (Wahyuni, et.al, 2014).

Pada konteks pemerintah daerah, dengan adanya kejelasan sasaran anggaran maka aparat pelaksana akan terbantu dalam merealisasikannya, dan ini akan mempengaruhi kinerja aparat. Salah satu penyebab tidak efektifnya anggaran adalah karena adanya ketidakjelasan sasaran anggaran yang mengakibatkan aparat pemerintah daerah kesulitan dalam menyusun target anggaran. Dengan demikian adanya sasaran anggaran yang jelas, maka aparat pemerintah dalam hal ini masingmasing OPD dapat meningkatkan kinerjanya sesuai dengan target yang telah ditetapkan (Wahyuni, et.al, 2014).

Desentralisasi adalah pengalihan kewenangan dari tingkat pemerintahan yang lebih tinggi ke pemerintahan yang lebih rendah, baik di bidang legislatif, peradilan, maupun administratif. Struktur desentralisasi memberikan tanggung jawab yang lebih besar kepada manajer tingkat yang lebih rendah. desentralisasi tidak hanya berarti pengalihan wewenang dari pemerintah pusat ke pemerintah yang lebih luas tetapi juga pengalihan beberapa otoritas pemerintah dalam bentuk privatisasi (Mukharomah, 2018). Desentralisasi akan menentukan tingkat otonomi yang didelegasikan 
pada manajerial agar manajerial memiliki rasa tanggung jawab yang lebih besar terhadap perencanaan dan pengendalian aktivitas operasi serta membutuhkan informasi yang lebih banyak. Jadi organisasi yang strukturnya lebih terdesentralisasi seperti pelaksanaan otonomi daerah di Indonesia, para manajerial mempunyai otonomi yang lebih besar dalam proses pengambilan atau penetapan keputusan.

Adanya desentralisasi dalam wujud pelimpahan wewenang (dalam hal ini adalah pengambilan keputusan) dapat meningkatkan kinerja organisasi sektor publik. Dengan adanya desentralisasi satuan kerja dan para pegawai dapat meningkatkan kinerjanya karena lebih mengetahui kondisi masyarakat dan dapat menetapkan program-program yang tepat sasaran. Peningkatan kinerja didukung dengan sistem manajemen pemerintahan daerah yang terdesentralisasi. Desentralisasi berupa pelimpahan wewenang (dalam hal ini adalah pengambilan keputusan) terkait dengan alokasi sumber daya dan pelayanan jasa terhadap masyarakat. Desentralisasi menjaring partisipasi dari seluruh unit kerja yang ada dalam tubuh pemerintahan daerah. Partisipasi tiaptiap satuan kerja dalam proses penetapan sasaran sangat dibutuhkan (Wahyuni, 2014).

Akuntabilitas publik adalah pemberian informasi atas setiap aktivitas dan kinerja pemerintah kepada pihak-pihak yang berkepentingan. Penekanan utama akuntabilitas publik adalah pemberian informasi kepada publik dan konstitusi lainnya yang menjadi pemangku kepentingan (stakeholder) (Ernawilis, 2015).

Akuntabilitas publik sangat penting dalam peningkatan kinerja manejerial, karena dengan adanya akuntabilitas kepada masyarakat, masyarakat tidak hanya untuk mengetahui anggaran tersebut tetapi juga mengetahui pelaksanaan kegiatan yang dianggarkan sehingga pemerintah daerah berusaha dengan baik dalam melaksanakan seluruh perencanaan yang ada karena akan dinilai dan diawasi oleh masyarakat (Arum, 2016)

Dengan adanya akuntabilitas publik, pemerintah daerah memberikan pertanggung jawaban atas semua kegiatan yang dilaksanakan sehingga kinerja pemerintah daerah dapat dinilai baik oleh pihak internal, maupun oleh pihak eksternal, jadi dengan demikian akuntabilitas publik mempengaruhi peningkatan kinerja manajerial SKPD (Wahyuni, 2014).

\section{METODEPENELITIAN}

Penelitian ini dilakukan diseluruh OPD di lingkungan Kota Pekanbaru. Populasi dalam penelitian ini adalah Organisasi Perangkat Daerah (OPD), yang terdiri dari Sekretariat, Badan, Dinas, dan Kantor yang ada di lingkungan Kota Pekanbaru. Metode pengambilan sampel menggunakan metode purposive sampling. Jumlah sampel pada penelitian ini yaitu pada 31 instansi yang ada di Kota Pekanbaru.

Jenis data yang digunakan adalah data primer, dimana masingmasing instansi dipilih 4 responden untuk mengisi kuesioner yang telah tersedia sehingga total keseluruhan sampel yang di ambil adalah sebanyak 124 responden. Kuesioner yang telah terkumpul selanjutnya dianalisis untuk memperoleh keyakinan terhadap kevalidan atau tidaknya hasil yang diharapkan dengan mengeliminasi jawaban responden yang tidak memenuhi syarat sebuah kuesioner.

\section{Defenisi Operasional dan Pengukuran Variabel Kinerja Manajerial (Y)}


kinerja para individu dalam melaksanakan kegiatan manajerial, yang meliputi kegiatan perencanaan, investigasi, koordinasi, evaluasi, pengawasan, pengaturan staf, negoisasi, dan perwakilan (Wahyuni, Rasuli dan Diyanto, 2014).

Indikator yang digunakan untuk mengukur Kinerja Manajerial adalah Perencanaan, Investigasi, Koordinasi, Evaluasi, Pengawasan, Pemilihan Staff, Negoisasi, dan Perwakilan.(Wahyuni, Rasuli dan Diyanto, 2014).

\section{Partisipasi Anggaran (X1)}

Partisipasi anggaran merupakan keterlibatan bawahan dalam proses penganggaran, yang secara langsung memiliki pengaruh terhadap individu tersebut (Desy Lesmana, 2011) Indikator yang digunakan untuk mengukur partisipasi Anggaran adalah Keterlibatan proses, Rasa puas, Kepentingan berpendapat, Kesediaan berpendapat, Intensitas opini atau ide atau masukan (Desy Lesmana, 2011).

\section{Kejelasan Sasaran Anggaran (X2)}

Kejelasan sasaran anggaran merupakan sejauh mana tujuan anggaran ditetapkan secara jelas dan spesifik dengan tujuan agar anggaran tersebut dapat dimengerti oleh orang yang bertanggung-jawab atas pencapaian sasaran anggaran tersebut (Arum, 2016). Indikator variabel kejelasan sasaran anggaran adalah sebagai berikut: Tujuan umum dan tugas, mengukur kinerja, standar dan target pencapaian, jangka waktu pengerjaan, sasaran prioritas, tingkat kesulitan, dan koordinasi (Putra 2013).

\section{Desentralisasi (X3)}

Desentralisasi adalah delegasi otoritas pembuatan keputusan dalam organisasi dengan memberikan otoritas kepada manajer dalam berbagai tingkat operasional untuk membuat keputusan yang terkait dengan bidang pertanggungjawabannya . Indikator yang diukur adalah keuangan, program dan kegiatan, keterlibatan kegiatan, kepegawaian (Tarjono Dan Nugraha, 2015).

\section{Akuntabilitas Publik (X4)}

Akuntabilitas adalah kewajiban pihak pemegang amanah (agent) untuk memberikan pertanggungjawaban, menyajikan, melaporkan, dan meningkatkan segala aktivitas dan kegiatan yang menjadi tanggung jawabnya kepada pihak pemberi amanah (principal) yang memiliki hak dan kewenangan untuk meminta pertanggungjawaban tersebut (Susilowati, 2016). Indikator yang digunakan untuk mengukur Akuntabilitas publik adalah kejujuran dan akuntabilitas hukum, akuntabilitas proses, akuntabilitas program., kuntabilitas kebijakan (Wahyuni, Rasuli dan Diyanto, 2014).

\section{HASIL DAN PEMBAHASAN Hasil Penelelitian}

Penelitian ini menggunakan 124 kuesioner yuang ditujukan kepada OPD Kota Pekanbaru, yaitu Sekretariat, Badan, Dinas, dan Kantor yang ada di Kota Pekanbaru. Dari jumlah 124 kuesioner yang dikirim, kuesioner yang dikembalikan sebanyak 106 buah atau $85 \%$. Kuesioner yang tidak di isi dengan lengkap sebanyak 17 buah atau $16 \%$. Maka jumlah kuesioner yang dapat di analisis dan di olah sebanyak 89 atau $84 \%$. Tingkat respon sebesar $84 \%$ termasuk tinggi, maka data termasuk layak untuk dilakukan pengolahan data.

Kinerja manajerial di ukur dan di nilai dengan menggunakan 8 item pernyataan. Jumlah total jawaban 
responden sebesar 2.438 dengan nilai minimal sebesar 712 , nilai maksimal sebesar 3.560, dan rata-rata diperoleh skor 3,4 , sedangkan kriteria posisi sebesar $68 \%$ termasuk di posisi $61 \%$ $80 \%$ (tinggi), artinya tujuan dan kebijakan rencana kegiatan sudah ditentukan sesuai seperti penjadwalan kerja; melaksanakan penyusunan anggaran dan penyusunan program; berperan dalam pengumpulan dan penyiapan informasi yang biasanya berbentuk catatan dan laporan; ikut berperan dalam tukar menukar informasi dalam organisasi untuk mengkoordinasikan dan menyesuaikan laporan; mengevaluasi dan menilai rencana kerja, laporan kinerja maupun kerja yang diamati pada unit atau sub unit; mengarahkan, memimpin dan mengembangkan para bawahan yang ada pada unit atau sub unit, dengan perolehan masing masing skor sebesar 3,9, 3,9, 3,7, 3,5, 4,1.

Partisipasi anggaran di ukur dan di nilai dengan menggunakan 5 item pernyataan. Jumlah total jawaban responden sebesar 1.768 dengan nilai minimal sebesar 890, nilai maksimal sebesar 2.225, dan rata-rata diperoleh skor 4,0 , sedangkan kriteria posisi sebesar $79 \%$ termasuk di posisi $61 \%$ $80 \%$ (tinggi), artinya dalam menyusun anggaran, program, dan kegiatan, semua pihak sudah dilibatkan; responden memiliki kesempatan untuk menyampaikan pendapat/opini; semua pihak berkontribusi terhadap partisipasi anggaran sangat besar, dengan perolehan masing masing skor sebesar 4,0, 4,3, 4,0.

Kejelasan sasaran anggaran di ukur dan di nilai dengan menggunakan 7 item pernyataan. Jumlah total jawaban responden sebesar 2.504 dengan nilai minimal sebesar 623, nilai maksimal sebesar 3.115, dan rata-rata diperoleh skor 4,0 , sedangkan kriteria posisi sebesar $80 \%$ termasuk di posisi $61 \%$ $80 \%$ (tinggi), artinya memahami tugas yang diberikan dalam bekerja; memiliki sasaran yang jelas dalam melakukan pekerjaan; mempunyai batas waktu untuk mencapai sasaran pekerjaan; tim bekerja sama untuk mencapai sasaran, dengan perolehan masing masing skor sebesar 4,4, 4,1, 4,1, 4,3.

Desentralisasi di ukur dan di nilai dengan menggunakan 4 item pernyataan. Jumlah total jawaban responden sebesar 1.127 dengan nilai minimal sebesar 356 , nilai maksimal sebesar 1.780, dan rata-rata diperoleh skor 3,2 , sedangkan kriteria posisi sebesar $63 \%$ termasuk di posisi $61 \%$ $80 \%$ (tinggi), artinya responden mempunyai wewenang untuk menentukan prioritas kegiatan yang akan dilaksanakan dan memiliki wewenang untuk menentukan pegawai yang terlibat dalam program kegiatan, dengan perolehan masing masing skor sebesar 3,6 dan 3,2.

Akuntabilitas publik di ukur dan di nilai dengan menggunakan 4 item pernyataan. Jumlah total jawaban responden sebesar 1.417 dengan nilai minimal sebesar 356, nilai maksimal sebesar 1.780, dan rata-rata diperoleh skor 4,0 , sedangkan kriteria posisi sebesar $79 \%$ termasuk di posisi $61 \%$ $80 \%$ (tinggi), artinya pelaksanaan kegiatan pelaporan pertanggungjawaban sesuai kondisi dan hasil yang ada, serta penggunaan anggaran telah didasarkan atas hukum dan peraturan yang berlaku; prosedur yang digunakan dalam melaksakan program kegiatan telah sesuai dengan prosedur administrasi, sistem informasi akuntansi, dan sistem informasi manajemen; Programprogram anggaran dirancang dengan prinsip efektifitas dan efesiensi dengan mempertimbangan pencapaian target serta hasil output maksimal, dengan 
perolehan masing masing skor sebesar 4,0 .

\section{Uji Kualitas Data}

Hasil uji kualitas data untuk variabel partisipasi anggaran, kejelasan sasaran anggaran, desentralisasi, dan akuntabilitas publik diperoleh dari nilai $\mathrm{r}$ tabel, dengan tingkat signifikansi $\alpha=$ $5 \%$ pada persamaan $\mathrm{N}-2=89-2=87$ atau 0,208. Nilai $r$ hitung dalam uji validitas menggunakan teknik Corrected Item Total Correlation. Dari hasil uji validitas, diketahui nilai $r$ hitung $>r$ tabel $(0,208)$, artinya seluruh item variabel komitmen organisasi, partisipasi anggaran, kejelasan sasaran anggaran, desentralisasi, dan akuntabilitas publik dinyatakan valid.

Reliabilitas data diuji dengan menghitung Cronbach's Alpha, dimana variabel dikatakan baik jika memiliki nilai Cronbach's Alpha > 0,60. Berdasarkan hasil pengujian, Cronbach's Alpha untuk variabel kinerja manajerial sebesar 0,853 >0,60, partisipasi anggaran sebesar 0,799 > 0,60, kejelasan sasaran anggaran sebesar $0,840>0,60$, desentralisasi sebesar 0,871>0,60, dan akuntabilitas publik sebesar $0,930>0,60$, dengan demikian dapat disimpulkan bahwa alat ukur yang digunakan dalam penelitian ini reliabel, karena Cronbach's Alpha> 0,60 .

\section{Uji Asumsi Klasik}

Hasil uji normalitas pada penelitian ini dapat di lihat dari OneSample Kolmogorov-Smirnov Test. Kriteria uji normalitas data menurut Priyatno 2012 “ Jika nilai signifkansi (Asym Sig 2 tailed) $>0,05$, maka data berdistribusi normal, dan jika nilai signifkansi (Asym Sig 2 tailed) $<0,05$, maka data tidak berdistribusi normal
(Priyatno, 2012). Hasil uji normalitas data dapat dilihat dari tabel dibawah ini:

Tabel 1. One-Sample Kolmogorov-Smirnov Test

One-Sample Kolmogorov-Smirnov Test

\begin{tabular}{|c|c|c|}
\hline & & $\begin{array}{l}\text { Unstandardized } \\
\text { Residual }\end{array}$ \\
\hline \multicolumn{2}{|l|}{$\mathrm{N}$} & 89 \\
\hline \multirow{2}{*}{$\begin{array}{l}\text { Normal } \\
\text { Parameters }^{\mathrm{a}, \mathrm{b}}\end{array}$} & Mean & .0000000 \\
\hline & $\begin{array}{l}\text { Std. } \\
\text { Deviation }\end{array}$ & 3.50090957 \\
\hline \multirow{3}{*}{$\begin{array}{l}\text { Most Extren } \\
\text { Differences }\end{array}$} & Absolute & .077 \\
\hline & Positive & .077 \\
\hline & Negative & -.063 \\
\hline \multicolumn{2}{|c|}{ Kolmogorov-Smirnov Z } & .731 \\
\hline \multicolumn{2}{|c|}{ Asymp. Sig. (2-tailed) } & .660 \\
\hline
\end{tabular}

Dari tabel diatas, hasil uji normalitas diketahui bahwa nilai signifikansi (Asymp.Sig 2-tailed) sebesar 0,660. Karena nilai signifikansi lebih dari 0,05, maka residual ini berdistribusi normal.

Model regresi dikatakan baik, jika tidak terjadi korelasi diantara variabel independen. Nilai cutoff yang umum dipakai untuk menunjukkan adanya multikolenieritas adalah jika nilai toleransi $>0,1$ atau sama dengan nilai VIF $<10$ dapat dikatakan dalam data tersebut terdapat multikolinearitas (Priyatno Duwi, 2013). Hasil pengujian menunjukkan bahwa hipotesis penelitian diperoleh nilai tolerance $>$ 0,1 dan nilai $\mathrm{VIF}<$ dari 10 . Hal ini dapat disimpulkan bahwa model regresi tersebut bebas dari multikolenieritas.

Pengujian
mendeteksi $\begin{array}{r}\text { selanjutnya } \\ \text { tidaknya }\end{array}$
heteroskedastisitas yang di lihat dari
grafik scatter plot. Jika titik-titik
membentuk pola tertentu, maka terdapat
heterokedastisitas, dan jika memiliki
titik-titik yang menyebar, maka dapat di
simpulkan bahwa tidak terdapat
heteroskedastistas. Hasil pengujian


heterokedastisitas dapat dilihat pada gambar 1:

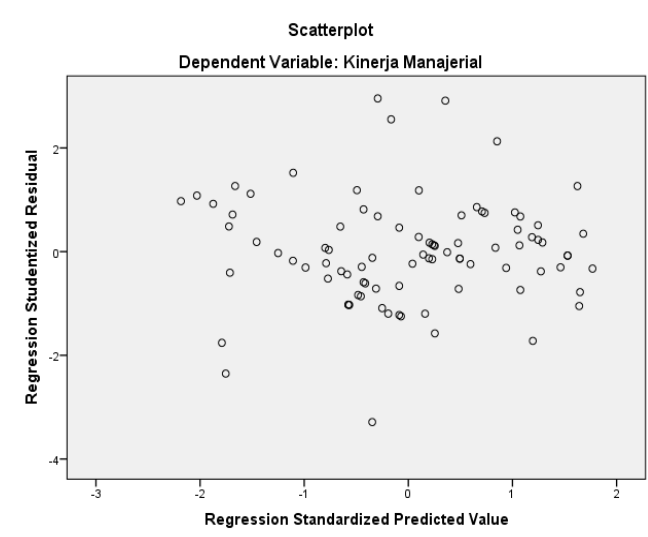

Gambar 1. Grafik Scatterplot

Hasil Analisis Regresi

Tabel 2. Hasil Analisi Regresi Linier Berganda

\begin{tabular}{|c|c|c|c|c|}
\hline Variabel & $\begin{array}{l}\text { Koefisie } \\
\text { n }\end{array}$ & $\begin{array}{c}\text { Std. } \\
\text { Error }\end{array}$ & T Hitung & Sig. \\
\hline Konstanta & $-0,500$ & - & - & - \\
\hline $\begin{array}{l}\text { Partisipasi Anggaran } \\
\text { (X1) }\end{array}$ & 1,249 & 0,153 & 8,183 & 0,000 \\
\hline $\begin{array}{l}\text { Kejelasan Sasaran } \\
\text { Anggaran (X2) }\end{array}$ & $-0,015$ & 0,142 & $-0,105$ & 0,917 \\
\hline Desentralisasi (X3) & 0,416 & 0,133 & 3,118 & 0,002 \\
\hline $\begin{array}{l}\text { Akuntabilitas Publik } \\
\text { (X4) }\end{array}$ & $-0,168$ & 0,201 & 0,832 & 0,408 \\
\hline $\mathrm{R}^{2}=0,525$ & F hitu & $=23,221$ & $\operatorname{Sig}=0,000$ & $\mathrm{~N}=89$ \\
\hline
\end{tabular}

Sumber : Data olahan 2020

Berdasarkan tabel diatas, hasil pengujian hipotesis dengan menggunakan persamaan regresi adalah sebagai berikut :

$\mathrm{Y}=-0,500+1,249 \mathrm{X}_{1}-0,015 \mathrm{X}_{2}+$ $0,416 \mathrm{X}_{3}-0,168 \mathrm{X}_{4}$

\section{Hasil Koefisien Determinan}

Dari hasil pengolahan data, nilai adjusted $R^{2}$ sebesar 0,503. Maka dapat disimpulkan pengaruh partisipasi anggaran, kejelasan sasaran anggaran, desentralisasi, dan akuntabilitas publik terhadap kinerja manajerial pada
Organisasi Perangkat Daerah (OPD) Kota Pekanbaru sebesar 50,3\% dan sisanya sebesar $49,7 \%$ dipengaruhi oleh faktor lain yang tidak termasuk dalam penelitian ini.

\section{Pengujian Hipotesis 1 dan pembahasn}

Pengaruh partisipasi anggaran (X1) terhadap kinerja manajerial (Y), terlihat bahwa $t_{\text {hitung }}>\mathrm{t}$ tabel $(8,183>$ 1,662) dengan nilai signifikan sebesar 0,000 dan tingkat kesalahan (alpha) sebesar 0,05. Dari hasil pengujian hipotesis pertama, maka keputusannya adalah Ha diterima dan Ho ditolak. Hasil uji $t$ menunjukkan bahwa partsipasi anggaran mempunyai pengaruh signifikan terhadap kinerja manajerial OPD Kota Pekanbaru.

Hasil penelitian ini didukung oleh Sari (2016); Susilowati (2016); Heski (2017) menganalisis dengan menggunakan analisis linier berganda, dimana menemukan bahwa partisipasi anggaran memiliki pengaruh terhadap kinerja manjerial SKPD Pemerintah daerah. Menurut kondisi praktisnya di lapangan, partsipasi penyusunan anggaran berhubungan langsung terhadap kinerja manajerial, jadi atasan memberikan tanggungjawab terhadap bawahan maupun pegawai SKPD untuk terlibat dalam penyusunan anggaran.Namun hanya bawahan maupun pegawai SKPD yang mampu menyusun dalam anggaran dan berpengalaman dalam anggaran.

Penelitian ini bertentangan dengan Ermawati, (2017), dimana hasil penelitiannya menemukan bahwa partisipasi penyusunan anggaran tidak berpengaruh terhadap kinerja manajerial SKPD Pati. Hal ini dikarenakan rendahnya keterlibatan SKPD Pati dalam proses penyusunan anggaran. Keterlibatan yang dilakukan hanya sebatas perencanaan saja dan kewajiban 
ikut serta, namun keterlibatan itu tidak diimbangi dengan partisipasi pegawai dalam memberikan id-ide yang kreatif.

\section{Hasil Pengujian Hipotesis Kedua}

Pengaruh kejelasan sasaran anggaran (X2) terhadap kinerja manajerial $(\mathrm{Y})$, terlihat bahwa $\mathrm{t}_{\text {hitung }}<\mathrm{t}$ tabel $(-0,105,832<1,662)$ dengan nilai signifikan sebesar 0,917 dan tingkat kesalahan (alpha) sebesar 0,05. Dari hasil pengujian hipotesis kedua, maka keputusannya adalah Ha ditolak dan Ho diterima, artinya, kejelasan sasaran anggaran tidak berpengaruh terhadap kinerja manajerial OPD Kota Pekanbaru.

Hasil penelitian didukung oleh Amril, (2014); Wahyuni, et.al, (2014), yang menyatakan bahwa kejelasan sasaran anggaran tidak memiliki pengaruh terhadap kinerja manajerial. Sesuai dengan teori yang disampaikan Morris dalam Wahyuni (2014), menurutnya ada atau tidaknya sasaran anggaran yang jelas, tidak akan berpengaruh terhadap kinerja, hanya saja tergantung pada bagaimana cara seorang pimpinan SKPD/ kabag/kabid/ kasubbag atau yang terlibat dalam pelaksanaan anggaran dalam menentukan sasaran (target) anggaran. Jika mereka berprinsip harus senantiasa melakukan yang terbaik yang dapat mereka lakukan, maka perhatian terhadap bagaimana target anggaran yang sudah dicapai dengan seperti yang diharapkan tidak akan menjadi penting, artinya apakah sasaran anggaran mereka sudah dinyatakan dengan jelas atau tidak, maka tidak akan berpengaruh terhadap kinerja mereka.

Dalam konteks pemerintah daerah, pemerintah daerah sulit dalam menetapkan sasaran karena adanya berbagai kepentingan stakeholder.
Terlebih lagi adanya unsur politik didalam lingkungan pemerintah daerah itu sendiri. Jadi baik atau tidaknya pengukuran kinerja sebaiknya tidak hanya dilihat dari aspek keberhasilan anggaran saja. Ini mengingat karena adanya muatan politik dalam anggaran sektor publik.

Berbeda dengan hasil penelitian Hidayat (2015); Putra (2013), bahwa adanya kejelasan sasaran anggaran mengacu pada anggaran yang telah dibuat dan dapat dimengerti secara jelas dan spesifik sesuai dengan apa yang telah direncanakan sebelumnya berdampak baik terhadap kinerja atau aktivitas manajerial dari aparat itu sendiri. Fakta yang ditemukan dilapangan menunjukan hubungan yang sesuai satu sama lain dimana dengan adanya kejelasan sasaran anggaran maka aparat dapat menentukan target dalam mencapai anggaran tersebut, dan merumuskan apa saja yang akan dilakukan sehingga apa yang telah ditargetkan pada awalnya dapat terealisasi dengan baik.

\section{Hasil Pengujian Hipotesis Ketiga}

Pengaruh desentralisasi terhadap kinerja manajerial OPD terlihat nilai $\mathrm{t}$ hitung 3,118 $>\mathrm{t}$ tabel 1,662 dengan taraf signifikan $0,002 \quad(<0,05)$ dan tingkat kesalahan (alpha) sebesar 0,05. Dari hasil pengujian hipotesis ketiga, maka keputusannya adalah Ha diterima dan Ho ditolak, artinya, kejelasan sasaran anggaran berpengaruh signifikan terhadap kinerja manajerial OPD Kota Pekanbaru.

Hasil penelitian Ini didukung oleh Darmawan (2016); Ernawilis (2015); Heski, (2017), hasil penelitiannya Desentralisasi memiliki pengaruh yang positif terhadap kinerja manajerial. Sesuai dengan kondisi praktis di bidang desentralisasi yang berkaitan langsung dengan kinerja 
manajerial, atasan memberikan desentralisasi kepada bawahan dan pegawai SKPD agar kinerjanya lebih baik, efisien dan mampu memberikan tanggung jawab atas pelaksanaannya terkait dengan anggaran. Hal ini menunjukkan bahwa semakin tinggi tingkat desentralisasi maka semakin baik kualitas kinerja aparatur pemerintah daerah.

Berbeda dengan hasil penelitian Mukaromah (2018), dimana hasil penelitiannya menyimpulkan bahwa desentralisasi tidak berpengaruh terhadap kinerja manajerial. Desentralisasi pada organisasi sektor publik yang kurang baik akan berakibat pada kurangnya struktur desentralisasi pada masing-masing SKPD tersebut, dimana seorang pemimpin tidak dapat dengan baik menjalankan kewenangan atas bawahannya dalam penetapan atau pengambilan keputusan, sehingga kualitas kinerja manajerial pada SKPD Karanganyar dikatakan masih rendah (Mukharomah, 2018).

\section{Hasil Pengujian Hipotesis Keempat}

Pengaruh akuntabilitas publik (X4) terhadap kinerja manajerial (Y), terlihat bahwa $\mathrm{t}_{\text {hitung }}<\mathrm{t}$ tabel $(0,832<$ 1,662) dengan nilai signifikan sebesar 0,408 dan tingkat kesalahan (alpha) sebesar 0,05. Dari hasil pengujian hipotesis keempat, maka keputusannya adalah Ha ditolak dan Ho diterima, artinya, tidak ada pengaruh antara akuntabilitas publik dengan kinerja manajerial pada OPD Kota Pekanbaru.

Penelitian ini didukung oleh Arum (2016); Heski, (2017). Arum berpendapat bahwa ini membuktikan bahwa dengan adanya akuntabilitas publik belum tentu dapat meningkatkan kinerja SKPD. Menurut Arum (2016), aparatur pemerintah daerah Kabupaten Lima Puluh Kota belum memberikan pertanggungjawaban atas semua aktivitas dan kegiatan yang dilakukan yang harus dilaporkan dan dipertanggungjawabkan kepada DPRD dan masyarakat. Atasan akan memberikan tanggungjawab sebagai amanah terhadap bawahan maupun pegawai SKPD agar kinerjanya lebih baik, namun hasilnya tidak efisien dalam kinerjanya dan tidak mampu memberikan tanggungjawab atas pelaksanaanya tentang anggaran.

Hasil penelitian ini tidak didukung oleh Darmawan (2016); Susilowati (2016), dimana dari hasil penelitian mereka menemukan bahwa terdapat pengaruh akuntabilitas publik dengan kinerja manajerial pada SKPD Kabupaten Bengkalis dan Kampar. Hal ini dikarenakan pihak-pihak yang bersangkutan dapat memberikan pertanggungjawaban, menyajikan, melaporkan, dan mengungkapkan aktivitas atau kegiatan yang dilakukan.

\section{PENUTUP Kesimpulan}

Berdasarkan hasil pengujian hipotesis menunjukkan bahwa variabel kejelasan sasaran anggaran dan akuntabilitas publik tidak berpengaruh terhadap kinerja manajerial OPD Kota Pekanbaru, sedangkan variabel partisipasi anggaran dan desentralisasi dibuktikan berpengaruh terhadap kinerja manajerial OPD Kota Pekanbaru. Artinya, bahwa adanya sasaran anggaran yang jelas serta bentuk pertanggungjawaban kepada publik tidak dapat mempengaruhi bagus atau tidaknya kinerja yang dihasilkan. Kemudian juga dapat disimpulkan bahwa aparatur pemerintah yang terlibat dalam proses penyusunan anggaran akan meningkatkan kinerja manajerial yang diikuti dengan penerapan desentralisasi, semakin tinggi penerapan desentralisasi dalam suatu OPD maka 
semakin baik pula kinerja manajerial OPD.

\section{Saran}

Penelitian ini hanya terbatas pada variabel partisipasi anggaran, kejelasan sasaran anggaran, desentralisasi, dan akuntabilitas publik yang merupakan sebagian kecil variabel yang dapat mempengaruhi kinerja manajerial. Oleh karena itu untuk penelitian selanjutnya, dapat mengambil ruang lingkup yang lebih luas atau perlu memasukkan variabel moderating yang mungkin dapat mempengaruhi kinerja manajerial OPD.

\section{DAFTAR PUSTAKA}

Amril, V.,N. (2014). Pengaruh Akuntabilitas Publik, Partisipasi Penyusunan Anggaran Dan Kejelasan Sasaran Anggaran Terhadap Kinerja Manajerial SKPD (Studi Empiris Pada Satuan Kerja Perangkat Daerah Di Kabupaten Sijunjung). Skripsi. Fakultas Ekonomi UNP.

Arum, N., S. (2016). Pengaruh Partisipasi Penyusunan Anggaran, Kejelasan Sasaran Anggaran, Dan Akuntabilitas Publik Terhadap Kinerja Manajerial OPD (studi pada OPD pemerintah daerah Kabupaten Lima Puluh Kota). Jom Fekon, 3(1).

Darmawan. (2016). Pengaruh Akuntabilitas Publik, Kejelasan Sasaran Anggaran,

Desentralisasi Dan Sistem Pengendalian Intern Terhadap Kinerja Manajerial Di OPD Kabupaten Bengkalis. Jom Fekom. 3(1).
Ermawati. (2017). Pengaruh Partisipasi Anggaran Terhadap Kinerja Manajerial Dengan Motivasi Kerja Sebagai Variabel Pemoderasi. Jurnal Akuntansi Indonesia, 6(2): 141 - 156.

Ernawilis. (2015). Pengaruh Akuntabilitas Publik, Partisiasi Penyusunan Anggaran, Kejelasan Sasaran Anggaran Dan Struktur Desentralisasi Terhadap Kinerja Aparat Pemerintah Daerah OPD Dengan Pengawasan Internal Sebagai Variabel Pemoderasi Kabupaten Kuantang Singing. Jom fekom, 2(2): 1-14.

Heski, P., Fidayati. (2017). Pengaruh Partisipasi Penyusunan

Anggaran, Kejelasan Sasaran Anggaran, Akuntabilitas Publik dan Struktur Desentralisasi terhadap Kinerja Manajerial (Studi Empiris pada OPD Kabupaten Magelang). University Research Colloqium (URECOL).

Hidayat T. (2015). Pengaruh Kejelasan Sasaran Anggaran, Struktur Desentralisasi Dan Locus Of Control Terhadap Kinerja Manajerial. 8(2)

Hidrayadi. (2015). Pengaruh Desentralisasi, Partisipasi Anggaran, Komitmen Organisasi, dan Motivasi Kerja Terhadap Kinerja Manajerial SKPD Kota Pekanbaru. Jom Fekom, 2(2).

Ingkriwang, O., C. (2013). Pengaruh Desentralisasi Dan Sistem Akuntansi Manajemen Terhadap Kinerja Manajer Dealer Di Manado. Jurnal EMBA. 1(3): 818-825.

Lubis. (2011). Akuntansi Keperilakuan. Jakarta. Penerbit Salemba Empat. 
Mardiasmo. (2013). Reformasi Pengelolaan Keuangan Publik Menuju Akuntabilitas Publik, Makalah yang disampaikan dalam Kongres Ikatan Sarjana Ekonomi Indonesia (ISES).

Mukaromah. (2018). Pengaruh Partisipasi Anggaran, Desentralisasi, Akuntabilitas Publik Terhadap Kinerja Manajerial SKPD Dengan Pengawasan Internal Sebagai Variabel Moderasi (Studi pada Satuan Kerja Perangkat Daerah Karanganyar).

Putra, D. (2013). Pengaruh Akuntabilitas Publik Terhadap Kinerja Manajerial OPD, Dan Pengaruh Kejelasan Sasaran Anggaran Terhadap Kinerja Manajerial SKPD.

Sari, (2015) Pengaruh Partisipasi Penyusunan Anggaran, Akuntabilitas Publik, Desentralisasi, Dan Sistem Pengendalian Intern Terhadap Kinerja Manajerial Pemerintah Daerah (Studi Pada Skpd Kabupaten Kuantan Singingi). Jom Fekom, 3(1).

Susilowati. (2016). Pengaruh Partisipasi

Penyusunan

Anggaran,

Kejelasan Sasaran Anggaran, Akuntabilitas Publik, Evaluasi Anggaran Terhadap Kinerja Aparat Pemerintah Daerah (SKPD Kab. Kampar). Jom fekom, 3(1),

Wahyuni, Rasuli, \& Diyanto. (2014). Pengaruh Kejelasan Sasaran Anggaran, Desentralisasi Dan Akuntabilitas Publik Terhadap Kinerja Manajerial Satuan Kerja Perangkat Daerah (Studi empiris pada SKPD Pemerintah Kota Pekanbaru). Jom Fekom, 1(2). 